寄 畫

\section{地震予知の基本的問題 $(2)^{*}$}

\author{
東京都立 雪谷高等学校 \\ 宮 本 貞 夫 \\ (昭和 39 年 8 月 25 日受理)
}

The Fundamental Problem of

Predicting Earthquake

Sadao MiYamoto

Yukigaya High School in Tokyo

(Received Aug. 25, 1964)

1. 地震予知の種類（長期と短期予報）大地震の 1000 年以上の歴史から 統計的に長期的予報をする ことも防災組織確立の点から有意義であり大いにな されてしかるべきるのと思う．地震予知の近代的各 種器械の重点的配置計画にもこの長期予報の分類は 案外に充分には行われていないように思う。

地震波速度の研究や地殼変動の観測などから，某 地方に 1 月または 2 月以内の地震予知ができるとす れば短期予報の中に入れるのが一般的考光と思う。 筆者の主張したいのは，超高感度地震計なぞで大地 震の数時間前の異常で大地震を数時間前に予報する ことの実用性を地震学者が注目し，防災組織にもと り入れる計画をとり入れる研究をすべきであると考 える、筆者はこれを超短期予知なたは直前予知と名 らけたい，普通の短期予報と併用してさらに大きい 実用性が発揮できると思う。

2. 直前予知の実用性

一般には数時間前の直前予知は実用性はないとい らかも知れぬが，それは誤りと思う。東京などの大 都会ではサイレンまたは各種の警報機で各家の火元 を消し，退避の準備をさせるには充分に役にたつは ずである．もちろん精神的訓練と準備を平常から与 えておく必要がある。「1 年に 1 回位は不意に訓練 します」との考方方もよいと思う。もし予知が的中 しない時はどうして責任問題を解決するかなどは心 配しない方がよいと思う。筆者が昭和 34 年に国会

昭和 39 年 5 月 9 日 地震学会で発表
の科学技術特別委員会で予知について発言を許され て各委員ののべた意見の中に失敗を恐れずに研究を 発展させるようにと強い意見であつた。10 回の中 1 回でも成功すれば充分との意見であつた。社会的 不安を不必要に与えてはならぬので予知の発表は極 めて慎重を期し，確実性極めて大の時発表すべしと する一般論には筆者はもちろん賛成であることは当 然であるが, 従来の消極的態度を改めるべきである.

3. 南関東に徹底した予知の努力を集中すべきで ある. 河角博士は 100 年以内に南関東に大地震の 可能性を統計的に主張している，南関東に地かく変 動の方法などを主力とする各種の方法を徹底して器 械を設備することを，熱望する. 5 年毎や 1 年毎の 測量では不充分で，せめてジオジ・メーターを 10 数台を南関東に設備して 1 月または数日毎の観測を 徹底して行らべきである。

今後数 10 年後になんとか予知の可能性を検討する 資料をつくればよいとの安易な考光はすてて，せめ て日本の中枢の東京の地震予知に成功ずくく今か あらゆる努力を集中すべきではなかろらか. $100 \mathrm{~m}$ 位の穴を南関東だけでも 10 数本掘つて超高感度地 震計による直前予知も充分可能性あることを筆者は 訴えたいのである。

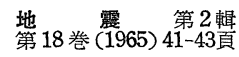

火山噴火予知の 基本的問 題

\author{
宮本貞夫 \\ (昭和 38 年 8 月 20 日受理)
}

The Fundamental Problem of

Predicting Volcanic Eruption Sadao Mryamoto

Yukigaya High School in Tokyo

(Received Aug. 20, 1963)

§1. 序

昭和 37 年度上り 40 年度にかけて, 気象庁は約 4 億円の費用で 要注意の各火山註 1 亿観測設備をし

$*$ 昭和 38 年 5 月地震学会で発表 
つつある現状を筆者は非常に喜ばしい事と思つてい る. $3000 \sim 5000$ 倍の倍率の三成分の電磁地震計で その前兆としての火山性地震を利用する方法であ る. 40 年度には特殊観測として，特定の火山には 地中温度測定も予定には入つているそうだが，情況 によつては更におくれるか子知れないとの事であ る. 地磁気観測は問題が複雑で原理的に疑問もある ので，今回の計画には入つていないそうである.

筆者も火山性地震の観測は是非必要と考学るが, この論文の目的は地中温度測定と地磁気観測の必要 性を筆者の見地によつてのべたい。

\section{$\S 2$ 地中温度測定の方法}

サーミスターを利用して 6 点の打点式の自記記録 装置を用いるのが経済的と考学る。サーミスターを 地中に埋めるには 2 種考えられる. 蒸気が弱線をた ぞつて出て来るすじ道に近い所で地表より数 $\mathrm{m} の$ 部分に埋める。これが最も有効と考える。サーミス ターの測定範囲は $-50^{\circ} \mathrm{C} \sim+350^{\circ} \mathrm{C}$ になつているか ら，充分に利用できる．別の埋め方は蒸気のたどる すじ道が全く不明の時, 火口に比較的近い且つ軟い 地層の中へ 10 数 数 $10 \mathrm{~m}$ 深く埋める方法で 6 本 位埋めれば，どれかが有効に働くかと考学る．記録 紙は 1 ケ月連続使用可能である。送り速度は $5 \mathrm{~cm} /$ h またはどんな值でも可能である. 難点はサーミ スターを保護する管である.

地質調査所の試錐課長とも相談した結果，ステン レス・スチールの内径 1 时位のもので打ち込んで埋 めるのがよいだろうとの事であつた．理由は硫黄の 昇華を抢それてもし，耐酸性のパイプを用いると， それは熱伝導性が悪いため小孔を空ける必要がある が，数年たてば，昇華物でつまると考光られる。ゆ えに穴の全くないステンレス・スチールの管ならそ の心配はない。耐酸性について理想的ではないとし ても 3 年に 1 回位管をとりかえるつもりになれば充 分と考学る.実はこの管については気象庁地震課の 火山係の方も難点として考兵ているとの事である.

\section{$\S 3$ 地温測定の意義}

筆者が日本地球電磁気学会で地温測定による火山 噴火予知を強調した時, 一部の学者は, 蒸気の活動 はすでに火山活動が始まつているから，噴火予知に
はならない。ゆ光にそれより早く変化するであろう 所の地磁気変化に重点を打いているのであるとのべ た。

筆者は地磁気測定に上る方法は誰よりも強く必要 性を痛感しているが，それと共に被害をもたらす噴 火活動の直前の蒸気の活動を地温測定で行ないたい のである.すなわち綜合的に行なら方が実用的と考 えるのである. 地磁気測定で 1 ケ月または 2 ケ月前 にその活動を予想し, 火山性地震でその数日前に噴 火活動を予知し，数時間または 2 日位前の蒸気の活 動で，噴火の直前の状態である事を予知しょうとす るものである. また別に化学的方法で蒸気の化学分 析的方法も出来机ば，併用したいと考光る．とにか くあらゆる方法を綜合的に行なつてこそ信頼性のあ る噴火予知が可能となるはずである。

上記の見解を筆者が強く持つに至つた理由は, 昭 和 37 年 8 月 24,25 日の三宅島の大噴火以後に千数 百回の火山性地震が数回あつたが，8 月 26 日以後 大噴火がなかつた事にある。単に火山性地震のみに 頼つたのでは稀にはこのように全く噴火予知洨力 のない事むあつて徒らに人々は心配するような情況 になるのである.もしこの時, 各種の方法がとられ ていれば，有効であつたか子知れないと思われる。 三宅島の昭和 15 年の著るしい大噴火の前には， 1 ケ月位前から地温上昇がはつきりと確認出来た例も あるのである。ゆえに火山のあるものには地温測定 が有効である可能性ありとの考は否定出来ない。ゆ 壳に如何に噴火の直前の現象かも知れない場合があ つたとしても, 予知の手段として地温測定もテスト として行なう価值は充分にあると思われる。

\section{$\S 4$ 地磁気測定の意義}

噴火予知の手段の 1 つとして, 地磁気測定もテス トとしては進めるべきものと思う。

東北大の加藤愛雄教授は三宅島の昭和 37 年 8 月 の大噴火の前後数年間に相当の変化ありとして伏角 の分布図を公表し, Fig. 1 の如くマグマの上昇に 上る温度上昇の効果に上る伏角減少（約数 $10 \gamma$ ）の 外に力学的原因による伏角变化も測定したとしてい るが，やはり研究段階である. 東大震研の行武は 三宅島のその噴火後だけの観測だが，半年位にわた クプロトン磁力計の全磁力の毎日の值と大島のそれ 


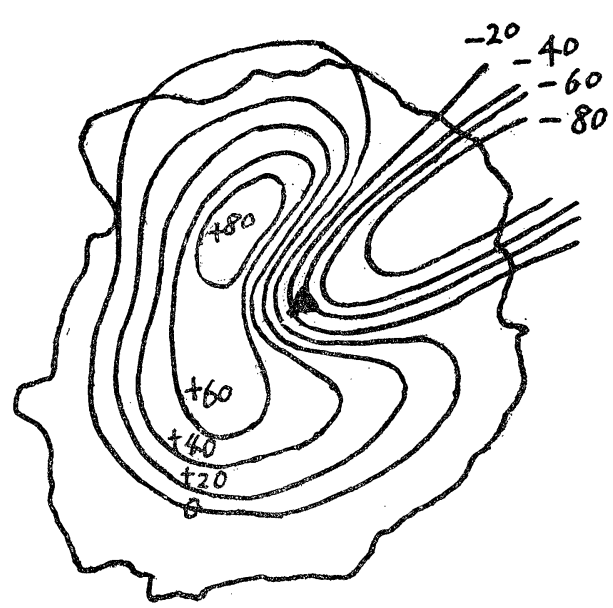

Fig. 1 Change of Inclination by Dr. Kato Miyake Is.

と比較して変化が極めて小さい $(10$ 数 $\gamma)$ として注 目されている. 行武らの見解では数力月の差で著し い変化のあつた地点は例外なく現地の人々が現状を 変化させたことがはつきりした。また現状がそのま まの地点では変化が少ないとして, 暗に数年毎の加 藤の比較には強い疑問を暗示している，第三者とし ての筆者はこれでは困ると考えるのである.すべて の要注意の火山に今直ちに行ならのは不可能として も, せめて三宅島や桜島だけでも地磁気の数地点で の連続観測が必要と考える。

また 1 カ月に 1 回でもよいから, 三宅島の全部に ついて数 10 地点で伏角観測を永久につつけて観測 をするのも必要と考える。その理由は東大震研が大 島の海岸の元町附近でプロトン磁力計の連続観測を 数年間乙ても，噴火とあ屯りよい関係は得られてい ないと聞く。しかるに大島の噴火と伏角の分布の良 い例が過去に力武が発表しているから，やはり伏角 の多数地点の 1 力月毎の分布図の必要性も感じるの である。

東北大の加藤博士の資料は 2 年とか 5 とか 6 年の 大きすぎる時間的間隔であり且つ地点も少なすぎる から説得力は第三者からみて少ないと思ら．もらろ ん一大学として行なら多くの研究の 1 つであるから 当然の止むを得ないことと筆者も考えるが，気象庁 または適当な国家機関が行ならとせば，困難なこと とは考えられない.へリコプターによる磁気測量も
1 年毎のくりかえしを要望する.

\section{§5. 結 語}

あらゆる方法を綜合してこそ火山噴火予知必始め て有効になると考えるのは筆者のみではないと考え る. 近頃, 外国では火山噴火による大きい被害も起 つているから，国際的に大いに貢献できるこの研究: が 1 日も早く国家機関の力で可能になることを熱望 している.

注 1.

昭和 38 年 3 月完了したもの 浅間山 (3) 桜島 (3), 昭和 39 年 3 月までに設備完了予定のもの

大島 (3), 阿蘇 (3)

三宅島 (1), 霧島 (1), 十勝岳 (1)

昭和 41 年 3 月までに設備完了の予定の女の (1) 雌 阿寒岳, 駒ケ岳, 有珠山, 樽前山, 吾妻山, 艋 梯山, 安達太良山, 雲仙岳, 鳥島

（）中の数字は電磁式地震計の三成分を 1 組と する組の数

地 18 巻震

$$
\begin{gathered}
\text { 初めの長さ零のバネ } \\
\text { の巻き少 }
\end{gathered}
$$

東京大学地震研究所 安芸敬一・安藤誠一 松本英照 (昭和 39 年 12 月 11 日受理)

How to make the Zero-length-spring

Keiiti AKI, Seiichi ANDo and Hideteru Matumoto

Earthquake Research Institute University of Tokyo (Received Dec. 11, 1964)

長周期上下動地震計としては， LaCoste のいわ。 ゆる “初めての長さ零のバネ”を用いるものが最も すぐれている.このバネを用いて，ある吊り方をする と, 振動の 2 次の項が消光て極めて安定な長周期振 子ができる，現在広く普及している Press-Ewing. 型地震計もこれを用いている. 